Prepared in cooperation with Colorado Springs Utilities

\title{
Elevation and Elevation-Change Maps of Fountain Creek, Southeastern Colorado, 2015-20
}

By Laura A. Hempel, Andrea L. Creighton, and Andrew R. Bock

Pamphlet to accompany

Scientific Investigations Map 3481 


\section{U.S. Geological Survey, Reston, Virginia: 2021}

For more information on the USGS - the Federal source for science about the Earth, its natural and living resources, natural hazards, and the environment—visit https://www.usgs.gov or call 1-888-ASK-USGS.

For an overview of USGS information products, including maps, imagery, and publications, visit https://store.usgs.gov/.

Any use of trade, firm, or product names is for descriptive purposes only and does not imply endorsement by the U.S. Government.

Although this information product, for the most part, is in the public domain, it also may contain copyrighted materials as noted in the text. Permission to reproduce copyrighted items must be secured from the copyright owner.

Suggested citation:

Hempel, L.A., Creighton, A.L., and Bock, A.R., 2021, Elevation and elevation-change maps of Fountain Creek, southeastern Colorado, 2015-20: U.S. Geological Survey Scientific Investigations Map 3481, 10 sheets, 12-p. pamphlet, https://doi.org/10.3133/sim3481.

Associated data for this publication:

Hempel, L.A., Creighton, A.L., and Kisfalusi, Z.D., 2020, Elevation data from Fountain Creek between Colorado Springs and the confluence of Fountain Creek at the Arkansas River, Colorado, 2020 (ver 2.0, May 2021): U.S. Geological Survey data release, https://doi.org/10.5066/P98J7DRO.

ISSN 2329-132X (online) 


\section{Acknowledgments}

The authors extend a special thanks to Colorado Springs Utilities for support of this project and are also grateful to the following individuals for providing access to their properties for data collection: Dave Kinnischtzke, Frank Masciantonio, and Ronald Anderson; without their collaboration, this report would not have been possible.

The authors also acknowledge U.S. Geological Survey colleague Rick Clawges for invaluable field assistance on this project. U.S. Geological Survey colleague Mark Bauer provided insight and guidance related to project design and data analysis. 



\section{Contents}

Acknowledgments ……...................................................................................................................

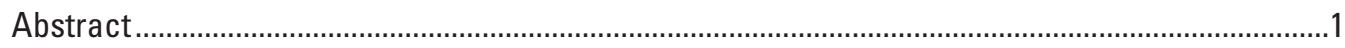

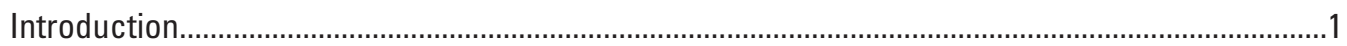

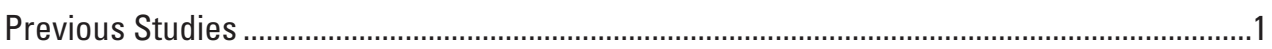

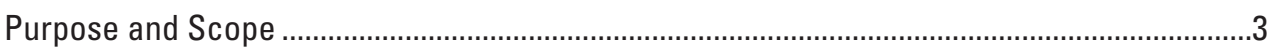

Study Area

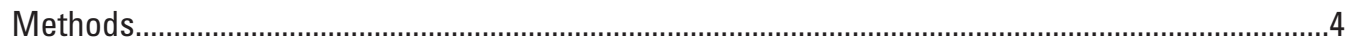

Topographic Data Collection with Real-Time Kinematic Global Navigation Satellite Systems ........................................................................................................

Topographic Data Collection with Light Detection and Ranging ...........................................5

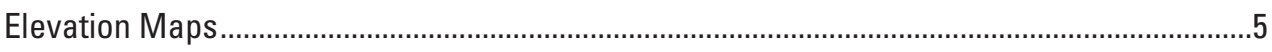

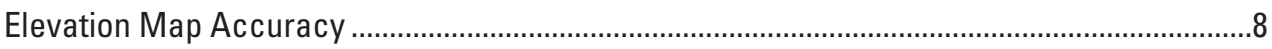

Elevation-Change Maps and Uncertainty Estimates .............................................................

Elevation-Change Maps and Geomorphic Changes between 2015 and 2020 .................................9

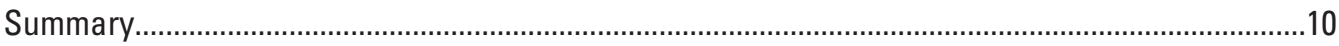

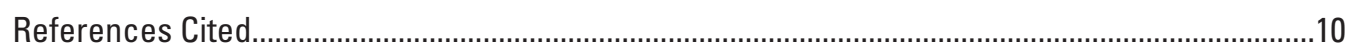

\section{Figure}

1. Map showing the 10 study areas along Fountain Creek between Colorado Springs and the terminus of Fountain Creek at the Arkansas River in Pueblo, Colorado ......

\section{Tables}

1. Summary of channel patterns for all 10 study areas on Fountain Creek, southeastern Colorado, based on the alluvial channel pattern classification developed by Schumm, 1985 .

2. Summary of point cloud errors from light detection and ranging surveys of the floodplain (non-wetted channel) at 10 study areas on Fountain Creek, southeastern Colorado, 2020

3. Parameters used to produce the ground-classified point clouds that were combined with other input data to generate the final digital elevation models used in elevation maps at 10 study areas on Fountain Creek, southeastern Colorado, 2020.

4. Survey point densities associated with the survey data on the floodplain and in the wetted channel used to generate the digital elevation models with 0.75 -meter square pixels used in final elevation maps at 10 study areas on Fountain Creek, southeastern Colorado, 2020

5. Summary of the combined horizontal and vertical uncertainties in digital elevation models ( $D$ from Fountain Creek, southeastern Colorado, 2020.

6. Standard deviation of error associated with re-sampled 2020 digital elevation models, elevation-change detection thresholds associated with the 95-percent confidence limit, and percentage of the study area that underwent detectable change for Fountain Creek elevation-change maps, 2015-20

7. Summary of geomorphic responses at all 10 study areas on Fountain Creek, southeastern Colorado, based on elevation-change maps, 2015-20 


\section{Map Sheets}

1. Elevation $(2015,2020)$ and Elevation-Change (2015-20) Maps-Study Area 01

2. Elevation $(2015,2020)$ and Elevation-Change (2015-20) Maps-Study Area 02

3. Elevation $(2015,2020)$ and Elevation-Change (2015-20) Maps-Study Area 03

4. Elevation $(2015,2020)$ and Elevation-Change (2015-20) Maps-Study Area 04

5. Elevation $(2015,2020)$ and Elevation-Change (2015-20) Maps-Study Area 05

6. Elevation $(2015,2020)$ and Elevation-Change (2015-20) Maps-Study Area 06

7. Elevation $(2015,2020)$ and Elevation-Change (2015-20) Maps-Study Area 07

8. Elevation $(2015,2020)$ and Elevation-Change (2015-20) Maps-Study Area 08

9. Elevation $(2015,2020)$ and Elevation-Change (2015-20) Maps-Study Area 09

10. Elevation $(2015,2020)$ and Elevation-Change (2015-20) Maps-Study Area 10

\section{Conversion Factors}

U.S. customary units to International System of Units

\begin{tabular}{lcl}
\hline \multicolumn{1}{c}{ Multiply } & By & \multicolumn{1}{c}{ To obtain } \\
\hline foot $(\mathrm{ft})$ & Length & \\
mile $(\mathrm{mi})$ & 0.3048 & meter $(\mathrm{m})$ \\
\hline \multicolumn{3}{c}{ Area } \\
\hline square foot $\left(\mathrm{ft}^{2}\right)$ & 1.609 & kilometer $(\mathrm{km})$ \\
square mile $\left(\mathrm{mi}^{2}\right)$ & 0.09290 & square meter $\left(\mathrm{m}^{2}\right)$ \\
& 2.590 & square kilometer $\left(\mathrm{km}^{2}\right)$ \\
\hline cubic foot $\left(\mathrm{ft}^{3}\right)$ & Volume & \\
\hline & 0.02832 & cubic meter $\left(\mathrm{m}^{3}\right)$ \\
\hline foot per second $(\mathrm{ft} / \mathrm{s})$ & Flow rate & \\
cubic foot per second $\left(\mathrm{ft}^{3} / \mathrm{s}\right)$ & 0.3048 & meter per second $(\mathrm{m} / \mathrm{s})$ \\
\hline
\end{tabular}

International System of Units to U.S. Customary Units

\begin{tabular}{|c|c|c|}
\hline Multiply & By & To obtain \\
\hline \multicolumn{3}{|c|}{ Length } \\
\hline meter $(\mathrm{m})$ & 3.281 & foot $(\mathrm{ft})$ \\
\hline kilometer (km) & 0.6214 & mile (mi) \\
\hline \multicolumn{3}{|c|}{ Area } \\
\hline square meter $\left(\mathrm{m}^{2}\right)$ & 10.76 & square foot $\left(\mathrm{ft}^{2}\right)$ \\
\hline square kilometer $\left(\mathrm{km}^{2}\right)$ & 0.3861 & square mile $\left(\mathrm{mi}^{2}\right)$ \\
\hline \multicolumn{3}{|c|}{ Volume } \\
\hline cubic meter $\left(\mathrm{m}^{3}\right)$ & 35.31 & cubic foot $\left(\mathrm{ft}^{3}\right)$ \\
\hline \multicolumn{3}{|c|}{ Flow rate } \\
\hline meter per second $(\mathrm{m} / \mathrm{s})$ & 3.281 & foot per second $(\mathrm{ft} / \mathrm{s})$ \\
\hline cubic meter per second $\left(\mathrm{m}^{3} / \mathrm{s}\right)$ & 35.31 & cubic foot per second $\left(\mathrm{ft}^{3} / \mathrm{s}\right)$ \\
\hline
\end{tabular}




\section{Datum}

Vertical coordinate information is referenced to the North American Vertical Datum of 1988 (NAVD 88).

Horizontal coordinate information is referenced to the North American Datum of 1983 (NAD 83).

Elevation, as used in this report, refers to distance above the vertical datum.

\section{Abbreviations}

$\begin{array}{ll}\text { 3D } & \text { three dimensional } \\ \text { CSU } & \text { Colorado Springs Utilities } \\ \text { DEM } & \text { digital elevation model } \\ \text { GCP } & \text { ground control point } \\ \text { lidar } & \text { light detection and ranging } \\ \text { ME } & \text { mean error } \\ \text { NAD 83 } & \text { North American Datum of 1983 } \\ \text { NAVD 88 } & \text { North American Vertical Datum of 1988 } \\ \text { RTK-GNSS } & \text { real-time kinematic Global Navigation Satellite Systems } \\ \text { RMSE } & \text { root-mean square error } \\ \text { SDE } & \text { standard deviation of error } \\ \text { SDS } & \text { Southern Delivery System } \\ \text { USGS } & \text { U.S. Geological Survey }\end{array}$





\title{
Elevation and Elevation-Change Maps of Fountain Creek, Southeastern Colorado, 2015-20
}

\author{
By Laura A. Hempel, Andrea L. Creighton, and Andrew R. Bock
}

\section{Abstract}

The U.S. Geological Survey, in cooperation with Colorado Springs Utilities, has collected topographic data annually since 2012 at 10 study areas along Fountain Creek, southeastern Colorado. The 10 study areas were located between Colorado Springs and the terminus of Fountain Creek at the Arkansas River in Pueblo. The purpose of this report is to present elevation maps based on topographic surveys collected in 2020 and to present maps of elevation change that occurred between 2015 and 2020 at all 10 study areas. Elevation and elevation-change maps were developed in Global Mapper, R, and ArcGIS from topographic surveys collected at each study area during the winters of 2015 and 2020. Topographic surveys in 2015 were completed using real-time kinematic Global Navigation Satellite Systems. Topographic surveys in 2020 were completed using both real-time kinematic Global Navigation Satellite Systems and light detection and ranging. Elevation-change maps were created using propagated uncertainties associated with the 95 -percent confidence limit. Study areas along Fountain Creek underwent a range of geomorphic responses between 2015 and 2020 that were often related to the dominant channel planform pattern of the study area. The results of this ongoing monitoring effort can be used to assess long-term changes in land-surface elevation and to advance understanding of the geomorphic response to possible changes in flow conditions on Fountain Creek.

\section{Introduction}

Fountain Creek is a perennial stream that flows through contrasting landscapes of the Colorado Front Range (fig. 1). A combination of natural events and anthropogenic changes throughout the Fountain Creek Basin, including wildfire, urbanization, transmountain diversions that bring water from the West slope, and more recently, treated wastewater discharge, have led to alterations in its hydrologic conditions since the late 1970s (Stogner, 2000; Sanderson and others, 2012). For example, to accommodate growing water demands caused by population growth in Colorado Springs, Colorado Springs Utilities (CSU) completed the Southern Delivery System (SDS) program in 2016 after 20 years of planning (Water Technology,
2019). The SDS transports water through an 80-kilometer long pipeline from Pueblo Reservoir to a water treatment plant in Colorado Springs for municipal use and then returns the treated wastewater to Fountain Creek and thus the Arkansas River (fig. 1) (Water Technology, 2019). The SDS water treatment plant has a full capacity of 50-million gallons per day, although initially, in 2016, it was only expected to operate at 10 percent capacity (SDS Water Treatment, 2019).

The U.S. Geological Survey (USGS), in cooperation with $\mathrm{CSU}$, established a monitoring program to increase understanding of the pace and style of geomorphic change on Fountain Creek by documenting baseline channel conditions in 2012 and tracking geomorphic changes following the implementation of the SDS in 2016. Annually, the USGS collects topographic data at 10 study areas located between Colorado Springs and the terminus of Fountain Creek at the Arkansas River in Pueblo and uses those data to generate elevation and elevation-change maps. The results of this ongoing monitoring effort can be used to assess long-term changes in land-surface elevation and to advance understanding of the geomorphic response to possible changes in flow conditions on Fountain Creek. More broadly, these data can be used to determine whether the current rate of change in channel morphology is similar to, slower than, or more rapid than historical rates of change. The data can also help determine the extent to which channel morphology changes can be simulated based on existing channel characteristics or flow patterns. In addition, the data could be used to identify riparian areas with infrastructure that may be susceptible to damage caused by changes in channel position or size.

\section{Previous Studies}

Previous flow assessment studies have been conducted in the Fountain Creek Basin that found overall increases in a range of flows since the development of water projects around 1980. In 2011, an environmental flow assessment was conducted for the Fountain Creek Basin using the Watershed Flow Evaluation Tool (Sanderson and others, 2012). Sanderson and others (2012) used data collected from four USGS streamgages within the Fountain Creek Basin located between Colorado Springs and Pueblo (USGS streamgages 07103700, 07105800, 07106300, and 07106500) operating between 1975 


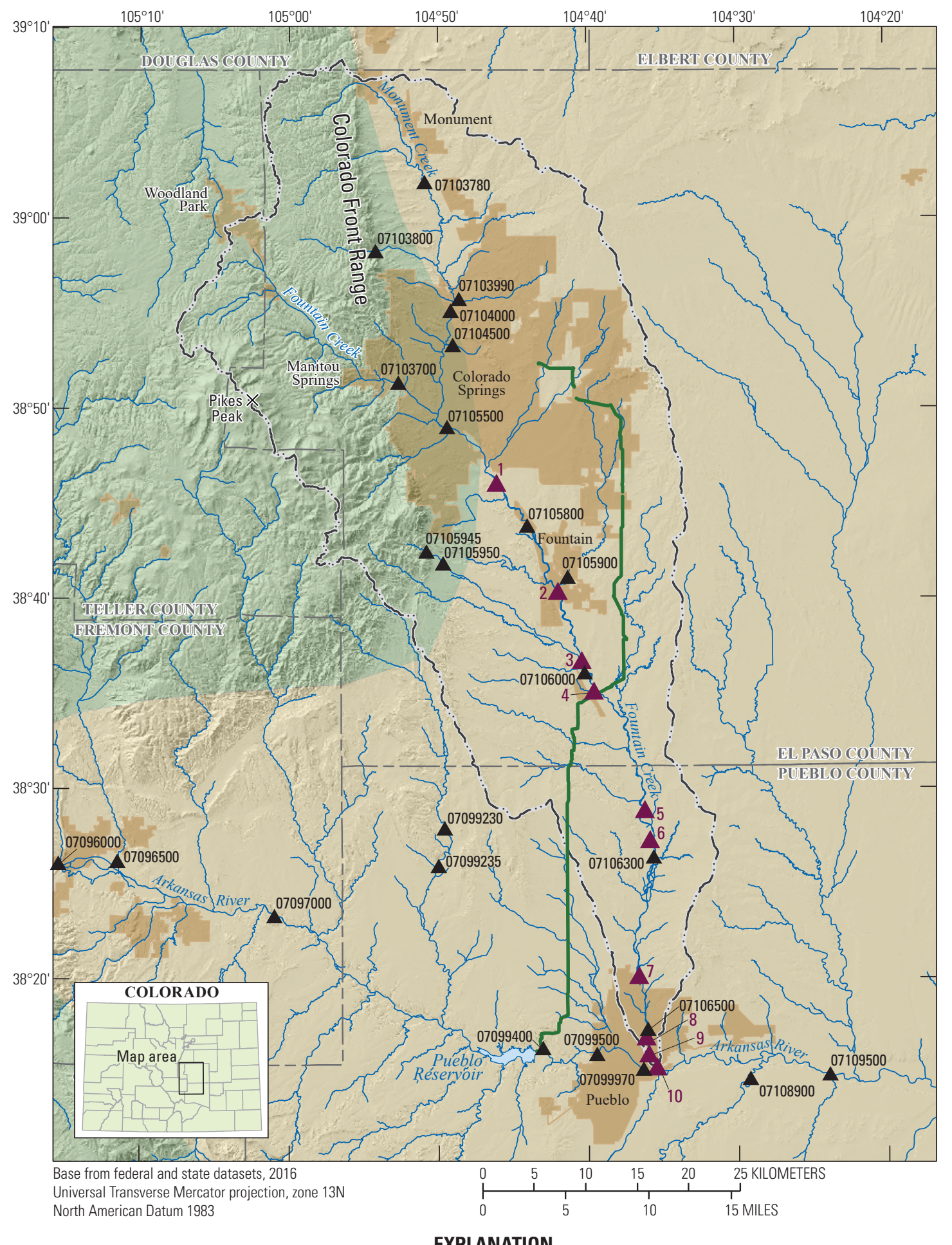

EXPLANATION
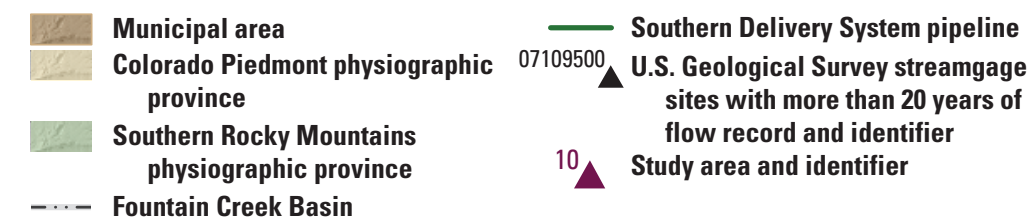

Figure 1. Map showing the 10 study areas along Fountain Creek between Colorado Springs and the terminus of Fountain Creek at the Arkansas River in Pueblo, Colorado. The Southern Delivery System pipeline in green follows from SDS Pipeline, 2014. Physiographic provinces adapted from Fenneman and Johnson, 1946. Figure from Hempel, 2020. 
and 2005 (fig. 1). The study found that mean-annual flows, peak flows, and seasonal flows during late-summer (August and September) and winter (January) have increased during the transition from natural to developed conditions and during the start of major water-supply projects. Increases in mean-annual flow were greater at the two southern sites (USGS streamgages 07106300 and 07106500) located near Pueblo (180-200 percent increase) compared to the two upper sites (USGS streamgages 07103700 and 07105800 ) located near Colorado Springs (30-45 percent increase); increases in winter, summer, and peak flows occurred at all sites and varied from 30 to 330 percent (Sanderson and others, 2012). As a result of increases in sub-bankfull flows, the erosion potential downstream from Colorado Springs has increased four- to fivefold (Sanderson and others, 2012).

Stogner (2000) studied flow patterns at six USGS streamgages from 1976 to 1999 between Colorado Springs and Pueblo (USGS streamgages 07104000, 07103700, 07105500, 07105800, 07106300, and 07106500). The results similarly found significant increases in daily mean flow corresponding to the 0th, 10th, 40th, 70th, 90th, and 100th percentiles. Stogner (2000) also found significant increases in the 7-, 14-, and 30-day high daily mean flow durations and increases in the 7-, 14-, and 30-day low-flow durations. Trends during the post-1976 period were roughly coincident with the timing of urbanization, population growth, and the implementation of water-supply projects marked by a shift in the relation between precipitation and flow from 1980 to 1982 based on a double mass curve analysis (Stogner, 2000).

The geomorphic effects of changes in flow on Fountain Creek are pronounced in some cases but can be difficult to disentangle from natural variability in other cases. For example, increases in sediment transport capacity and coarsening of the mean particle size on the streambed between 1999 and 2005 have been attributed to increases in treated wastewater discharge upstream from the current study areas (Mau and others, 2007). Other changes have been more spatially distributed making them difficult to attribute to a single factor. For example, downcutting was found to be the dominant channelshaping process throughout the urbanized section of Fountain Creek, located upstream from the city of Fountain, between 1999 and 2005, but no clear cause was identified (Mau and others, 2007).

Superimposed on more recent geomorphic changes to Fountain Creek are longer-term responses to catastrophic flooding. Results from a study of historical aerial photos (1947-99) indicate that peak-flow events with a recurrence interval of once every 5 years (annual exceedance probability of 0.2), based on the USGS streamgage record at Pueblo (streamgage 07106500) (greater than 283 cubic meters per second [10,000 cubic feet per second]), caused substantial morphologic changes including channel widening, rapid lateral migration, loss of mature riparian vegetation, and sediment deposition on the floodplain (Stogner, 2000). In contrast, during quiescent periods when peak flows did not exceed 283 cubic meters per second, more muted changes were observed, such as vegetation regrowth and localized bank erosion (Stogner, 2000). Changes in channel morphology may therefore be tied to flood cycles on Fountain Creek; channel morphology may change rapidly during high-flow events and re-establish a more stable channel pattern during low-flow periods (Stogner, 2000). Consequently, the current morphology of Fountain Creek may be closely related to the time since the last flood event.

\section{Purpose and Scope}

The purpose of this report is to present elevation maps based on topographic data collected in 2020 and to present maps of elevation change that occurred between 2015 and 2020 at 10 study areas located between Colorado Springs and the terminus of Fountain Creek at the Arkansas River in Pueblo, Colorado (fig. 1). This report includes (1) a detailed description of the methods used to develop elevation and elevation-change maps and estimate uncertainty in the maps, (2) elevation maps from 2020 and elevation-change maps between 2015, the year prior to the implementation of the SDS, and 2020 at all 10 study areas, and (3) a summary of geomorphic changes between 2015 and 2020 based on 95-percent confidence limit elevation-change maps. The workflows and elevation maps associated with digital elevation models (DEMs) from 2015 are published in Hempel (2020) and are not described in this publication.

\section{Study Area}

The Fountain Creek Basin is 2,401 square kilometers (927 square miles) and ranges in elevation from 1,414 to 4,301 meters $(4,640$ to 14,110 feet [Stogner, 2000]). The upper portion of Fountain Creek flows southeast from Woodland Park, Colorado (fig. 1). Monument Creek is a major tributary to Fountain Creek that originates near Monument, Colorado, and flows south along the mountain front. Downstream from the confluence of Fountain Creek and Monument Creek in Colorado Springs, the lower portion of Fountain Creek flows south-southeast through the communities of Fountain and Pueblo to its terminus at the Arkansas River in Pueblo (fig. 1).

Like many Colorado Front Range streams, Fountain Creek spans two physiographic provinces. The upper portion of the basin is located in the steep Southern Rocky Mountains, and the lower portion of the basin is located east of the mountains in the Colorado Piedmont (Fenneman, 1917; Trimble, 1980). Flow in the upper Fountain Creek Basin originates along the northern slopes of Pikes Peak where well-drained soils are underlain by the Middle Proterozoic-age Pikes Peak Granite (Larsen, 1981; Hansen and others, 1982; von Guerard, 1989). Land cover in the upper basin is predominantly alpine forest and shrubland (Sanderson and others, 2012), and stream morphology includes a mix of pool-riffle and bedrockconstricted step-pool morphologies. 
All 10 study areas are located in the lower portion of the Fountain Creek Basin (fig. 1) and span a range of geomorphic channel planform patterns based on the classification developed by Schumm (1985) (table 1). In contrast to the upper portion of the Fountain Creek Basin, the lower portion of the basin is in the low gradient Colorado Piedmont province where highly erodible soils and alluvial deposits are underlain by sedimentary rocks (Larsen, 1981; Hansen and others, 1982; von Guerard, 1989). Land cover in the lower portion of the basin is composed of arid grassland and prairie (Larsen, 1981; Hansen and others, 1982; von Guerard, 1989), and stream morphology is characterized as a meandering sand-bedded channel that is braided along several reaches.

\section{Methods}

Elevation and elevation-change maps were developed in Global Mapper, R, and ArcGIS from topographic surveys collected at each study area during the winters of 2015 and 2020 (Kohn, 2017; Hempel, 2020; Hempel and others, 2020a; Hempel and others, 2020b). Topographic surveys in 2015 were completed using real-time kinematic Global Navigation Satellite Systems (RTK-GNSS) (Kohn, 2017; Hempel, 2020), and topographic surveys in 2020 were completed using RTKGNSS and light detection and ranging (lidar).

Digital elevation models (DEMs) of the 10 Fountain Creek study areas were developed from topographic survey data acquired in 2020 (Hempel and others, 2020b). Airborne lidar was used to map topography of the floodplain, or non-wetted channel, and ground-based RTK-GNSS surveys were used to map topography of the wetted channel. Groundbased RTK-GNSS was also used to collect check points on the floodplain to assess the accuracies of lidar point clouds and of DEMs. Both lidar and RTK-GNSS survey data were combined to produce bare-earth DEMs of each study area.
Elevation-change maps were then created by first differencing the DEMs produced from topographic data collected in 2020 from DEMs produced from topographic data collected in 2015 (Kohn, 2017, Hempel, 2020, Hempel and others, 2020a, Hempel and others, 2020b). Elevation changes smaller than the elevation-change detection limit, defined by propagated uncertainties associated with the 95-percent confidence limit, were removed to produce the final elevation-change maps.

\section{Topographic Data Collection with Real-Time Kinematic Global Navigation Satellite Systems}

The wetted channel and at least 198 survey check points (to assess the accuracy of floodplains within DEMs) were surveyed at each of the 10 study areas between January 22 and March 31, 2020, using RTK-GNSS. Ground-based RTKGNSS survey points, rather than lidar survey points, were used to measure topography within the wetted channel because laser pulses emitted by the lidar sensor do not penetrate water (Hooshyar and others, 2015). The RTK-GNSS surveys were performed in the winter months to coincide with lidar surveys and seasonally low flows that are safe to wade. Survey techniques followed the methods outlined by Rydlund and Densmore (2012) and were consistent with techniques used in previous surveys of the Fountain Creek Basin from 2012 to 2019 (Kohn, 2017; Hempel, 2020). All survey data were collected in meters and in Universal Transverse Mercator coordinates. The horizontal coordinate system used was North American Datum 1983 (NAD 83), Zone 13 North, and the vertical coordinate system used was the North American Vertical Datum of 1988 (NAVD 88), Geoid 12B. Geoid 12B was used so that comparisons between elevation maps generated in different years were consistent.

At the start and end of each field day, at least one control point was surveyed by each surveyor for quality assurance and to ensure measurement uncertainty was less than the

Table 1. Summary of channel patterns for all 10 study areas on Fountain Creek, southeastern Colorado, based on the alluvial channel pattern classification developed by Schumm, 1985.

[The dominant channel pattern, or the pattern present in the majority of the study area, appears first for study areas where more than one channel pattern is listed]

\begin{tabular}{cc}
\hline Study area & Channel pattern \\
\hline 01 & Meandering, straight \\
02 & Straight \\
03 & Straight \\
04 & Meandering \\
05 & Meandering \\
06 & Braided, meandering \\
07 & Meandering \\
08 & Meandering, straight \\
09 & Straight, meandering \\
10 & Straight \\
\hline
\end{tabular}


user-defined tolerance for vertical and horizontal precisions (less than 0.15 meter [ 0.49 foot]). Survey points were collected with horizontal and vertical precisions less than 0.15 meter (0.49 foot) (Hempel and others, 2020b). The mean horizontal precision associated with both control points and survey points was 0.02 meter ( 0.08 foot), and the mean vertical precision associated with both control points and survey points was 0.03 meter ( 0.10 foot) (see Hempel and others [2020b] for the horizontal and vertical precisions associated with individual points).

Topographic surveys of the wetted channel were performed using a morphologically based sampling scheme to capture topographic complexities while minimizing errors (Brasington and others, 2000; Brasington and others, 2003; Heritage and others, 2009; Wheaton and others, 2010; Milan and others, 2011). In general, survey points within the wetted channel were collected in a grid pattern with a 5-meter spacing between points, although topographically complex areas were sampled at a smaller spacing. Points surveyed within the wetted channel were coded as "BED," standing for streambed. Points surveyed at the transition between abrupt breaks in slope, such as the tops or toes of streambanks, were coded as "BL," standing for break line. The break line points help improve the accuracy of interpolation within the wetted channel during data analysis. Points surveyed outside the wetted channel were coded as "FP," standing for floodplain. Because RTK-GNSS surveys of the wetted channel were not collected at the exact same time as lidar surveys, RTK-GNSS survey points were often collected beyond the extent of the wetted channel to cover areas that could be inundated if flows were higher at the time of the lidar surveys. In addition to surveys of the wetted channel, at least 198 RTK-GNSS survey check points were collected at spatially distributed locations throughout the floodplain (or non-wetted channel) at each study area in a mixture of vegetated and non-vegetated areas. Those check points were used to assess the accuracy of the floodplain within DEMs.

At the completion of RTK-GNSS surveys, the survey data were processed into tabular format, checked for quality by ensuring that the check-in and check-out control points were within measurement uncertainty, and then submitted to the Online Positioning User Service (OPUS) for correction (https://www.ngs.noaa.gov/OPUS/). The resulting topographic-survey data collected with RTK-GNSS in 2020 are published in Hempel and others (2020b).

In 2015, the entire study area (both the floodplain and wetted channel) was surveyed using the same RTK-GNSS techniques used in 2020, but at coarser resolution. The overall sampling scheme in 2015 involved surveying land-surface elevations along transect lines. Individual points were surveyed in a grid pattern, such that transects were roughly 4-12 meters (13-39 feet) apart, and points within each transect were spaced roughly 6-12 meters (20-39 feet) apart. See Kohn (2017) or Hempel (2020) for more information on the 2015 topographic survey.

\section{Topographic Data Collection with Light Detection and Ranging}

Lidar was used to map topography of the floodplain, or non-wetted channel. Airborne lidar surveys were carried out between March 10-13 and March 17-18, 2020, which coincided with RTK-GNSS surveys. The lidar surveys were performed in the winter months during leaf-off so that a greater number of ground surface points could be collected. The lidar surveys collected a minimum point density of 100 points per square meter and used the same base station locations as RTKGNSS surveys at each site.

Georeferenced point clouds were produced in LAS (LASer) file format and in the same horizontal and vertical datum as the RTK-GNSS surveys of the wetted channel and floodplain. All survey data were collected in meters and in Universal Transverse Mercator coordinates. The horizontal coordinate system used was NAD 83, European Petroleum Survey Group 6342, Zone 13 North, and the vertical coordinate system used was NAVD 88, Geoid 12B. Georeferenced point clouds of each study area are published in Hempel and others (2020b).

The RTK-GNSS ground control points (GCPs) were collected and used to assess the horizontal and vertical accuracies of lidar points clouds. At each study area, a minimum of 2-5 GCPs, consisting of RTK-GNSS surveyed reflectors 0.08 meter ( 0.29 foot) in diameter attached to wooden stakes driven into the ground, were used to assess the horizontal accuracy of the point cloud (table 2). A minimum of seven GCPs at each study area, consisting of RTK-GNSS survey points on the floodplain, were used to assess the vertical accuracy of the point could (table 2). The horizontal and vertical accuracies of each point cloud are reported in table 2 in terms of the root-mean-square error between the lidar points and GCPs. Horizontal errors were 0.043 meter ( 0.141 foot) or less, and vertical errors were 0.121 meter ( 0.397 foot) or less (table 2$)$.

\section{Elevation Maps}

Topographic-survey data were used to generate bareearth DEMs of each study area using Global Mapper version 21.1, ArcMap version 10.7.1, ArcScene version 10.7.1, and $\mathrm{R}$ statistical computing software version 3.5.1 (Global Mapper, 2020; Esri, 2020; R Core Team, 2020). The RTK-GNSS survey points within the wetted channel, three-dimensional (3D) break lines, and the ground classified lidar point clouds covering the floodplain (or non-wetted channel) were combined to produce the final DEMs used in elevation maps.

The lidar point clouds were first clipped to the extent of individual study areas and filtered to include only -60 to 60 degree scan angles in Global Mapper (Global Mapper, 2020). Scan angle refers to the rotational position of an emitted laser pulse, with zero degrees representing nadir and -90 
or 90 degrees representing the direction of flight to the left or right of the aircraft, respectively. Next, a polygon of the wetted channel was hand digitized from several datasets in ArcMap (Esri, 2020). Primarily, rasters of lidar point intensity were used to delineate the wetted channel because the contrast in point intensities is high between wetted areas and dry land areas (Hooshyar and others, 2015). Rasters of lidar point intensity (relative return strength of laser pulse) were produced in Global Mapper from ground-classified (non-vegetation) points using default settings (Global Mapper, 2020). Generally, point intensities less than 25,000 were indicative of the wetted channel based on the lidar data collected for this study. Rasters of elevation (preliminary DEMs) were also used to delineate the wetted channel in areas with steep streambanks. Those preliminary DEMs were produced in Global Mapper from ground-classified points using default settings and were not the same as the final DEMs used in elevation maps (Global Mapper, 2020). The final DEMs used in elevation maps were generated using a different workflow described later in this section. Lastly, RTK-GNSS survey points coded as "BED" for streambed or "BL" for break line were also used to delineate the wetted channel.

The RTK-GNSS points were refined prior to combining with lidar survey points to produce the final DEMs. Survey points that fell inside the wetted channel polygon were separated from those that fell outside the wetted channel polygon. Survey points that fell within the wetted channel were then converted to LAS file format and were classified as ground points using the Change Lidar Class tool in Global Mapper (Global Mapper, 2020).

The 3D break lines were generated along steep breaks in slope (for example, along streambanks) from RTK-GNSS survey points in ArcScene (Esri, 2020). The 3D break lines were generated by first extracting RTK-GNSS survey points along steep breaks in slope to a new shapefile. The extracted RTK-GNSS survey points were then converted from twodimensional shapefiles to 3D shapefiles using the Feature to $3 D$ by Attribute tool in ArcMap (Esri, 2020). The 3D break lines were delineated from 3D point shapefiles using the $3 D$ Editor in ArcScene (Esri, 2020).

Lidar points were refined prior to producing the final DEMs used in elevation maps. First, lidar points that fell within the wetted channel polygon were removed in Global Mapper (Global Mapper, 2020). Next, ground points were classified using a custom script that looped through different parameters within the Auto Classify Ground Points tool in Global Mapper to produce a suite of different ground-classified point clouds based upon varying combinations of usercontrolled input parameters (Global Mapper, 2020). The input parameters used to produce those point clouds ranged from 2- to 5-point spacings for the base bin size, 20 to 60 degrees for the expected terrain slope, and 0.20 to 0.40 meter for the minimum height departure, resulting in 80 different groundclassified point clouds.

The ground-classified point clouds were then combined with RTK-GNSS survey points within the wetted channel (in LAS format) and 3D break lines to produce 80 different bare-earth DEMs per study area using custom scripts in Global Mapper (Global Mapper, 2020). The DEMs were generated using pixel sizes of 0.75 meter (2.46 feet) and the average-binning grid creation method (Global Mapper, 2020). The errors associated with individual DEMs were estimated using $\mathrm{R}$. The bare-earth DEM that was characterized by the lowest standard deviation of error and lowest root-mean square error and was representative of the physical topography of the terrain was manually selected as the final DEM for the elevation map. The

Table 2. Summary of point cloud errors from light detection and ranging surveys of the floodplain (non-wetted channel) at 10 study areas on Fountain Creek, southeastern Colorado, 2020.

\begin{tabular}{ccccc}
\hline Study Area & $\begin{array}{c}\text { Horizontal accuracy, root } \\
\text { mean square error in } \\
\text { meters }\end{array}$ & $\begin{array}{c}\text { Number of ground control } \\
\text { points used to assess } \\
\text { horizontal accuracy }\end{array}$ & $\begin{array}{c}\text { Vertical accuracy, root } \\
\text { mean square error in } \\
\text { meters }\end{array}$ & $\begin{array}{c}\text { Number of ground control } \\
\text { points used to assess } \\
\text { vertical accuracy }\end{array}$ \\
\hline 01 & 0.036 & 5 & 0.052 & 13 \\
02 & 0.024 & 5 & 0.084 & 7 \\
03 & 0.038 & 4 & 0.047 & 11 \\
04 & 0.043 & 5 & 0.069 & 24 \\
05 & 0.043 & 5 & 0.038 & 31 \\
06 & 0.035 & 5 & 0.034 & 25 \\
07 & 0.029 & 4 & 0.087 & 19 \\
08 & 0.025 & 2 & 0.096 & 15 \\
09 & 0.031 & 5 & 0.121 & 30 \\
10 & 0.028 & 4 & 0.052 & 18.8 \\
\hline
\end{tabular}


parameters used to produce the ground-classified point clouds used to generate the final DEMs are summarized in table 3 (Global Mapper, 2020).

Lastly, areas encompassing human-made infrastructure characterized by poor survey quality and complex topography, that may have contributed to added uncertainty in the DEM, were delineated based on data collected in 2019 (Hempel, 2020) and added to elevation maps at study areas 2 and 10. Color scale-bars were adjusted to linearly span the maximum and minimum elevation values within each study area. The final elevation maps are presented in sheets $1-10$.

The survey point densities associated with the final DEMs are presented in table 4 . The mean survey point density based on RTK-GNSS data in the wetted channel was 0.14 point per pixel ( 0.75 meter by 0.75 meter), and survey point density based on lidar data on the floodplain, or non-wetted channel, was 83.00 points per pixel ( 0.75 meter by 0.75 meter).

The methods for generating 2015 DEMs differed because the input data consisted only of RTK-GNSS survey points (Hempel, 2020). Briefly, 2015 DEMs were created using the Natural Neighbor interpolation method within the TIN to Raster tool in ArcMap and clipped to the study area boundary (Esri, 2020). The 2015 elevation maps were generated with a coarser 2.0-meter (6.6-foot) pixel size because the 2015 survey point density was more sparse. Point densities associated with 2015 DEMs, in terms of survey points per pixel, ranged from 0.08 to 0.29 . See Hempel (2020) for more information on 2015 DEMs.

Table 3. Parameters used to produce the ground-classified point clouds that were combined with other input data to generate the final digital elevation models used in elevation maps at 10 study areas on Fountain Creek, southeastern Colorado, 2020.

\begin{tabular}{cccc}
\hline Study area & Base bin size, in point spacings & Terrain slope, in degrees & Minimum height departure, in meters \\
\hline 01 & 4 & 20 & 0.3 \\
02 & 2 & 20 & 0.2 \\
03 & 5 & 20 & 0.4 \\
04 & 4 & 60 & 0.2 \\
05 & 5 & 40 & 0.2 \\
06 & 5 & 20 & 0.3 \\
07 & 4 & 20 & 0.3 \\
08 & 5 & 20 & 0.2 \\
09 & 5 & 60 & 0.2 \\
10 & 5 & 40 & 0.4 \\
\hline
\end{tabular}

Table 4. Survey point densities associated with the survey data on the floodplain and in the wetted channel used to generate the digital elevation models (DEMs) with 0.75 -meter square pixels used in final elevation maps at 10 study areas on Fountain Creek, southeastern Colorado, 2020.

\begin{tabular}{|c|c|c|c|c|c|}
\hline Study Area & $\begin{array}{c}\text { Total study } \\
\text { area, in square } \\
\text { meters }\end{array}$ & $\begin{array}{l}\text { Number of survey } \\
\text { points on the } \\
\text { floodplain used to } \\
\text { generate DEMs }\end{array}$ & $\begin{array}{l}\text { Floodplain survey } \\
\text { density, in number of } \\
\text { survey points per pixel }\end{array}$ & $\begin{array}{l}\text { Number of survey points } \\
\text { in the wetted channel } \\
\text { used to generate DEMs }\end{array}$ & $\begin{array}{c}\text { Wetted channel } \\
\text { survey density, in } \\
\text { number of survey } \\
\text { points per pixel }\end{array}$ \\
\hline 02 & 48,286 & $6,329,597$ & 89.61 & 758 & 0.16 \\
\hline 03 & 78,250 & $9,164,721$ & 88.55 & 1,416 & 0.13 \\
\hline 05 & 147,377 & $16,900,882$ & 84.06 & 2,467 & 0.13 \\
\hline 06 & 441,396 & $57,470,412$ & 81.18 & 2,516 & 0.10 \\
\hline 07 & 113,089 & $13,077,506$ & 74.80 & 1,397 & 0.17 \\
\hline 08 & 187,430 & $24,419,673$ & 91.35 & 2,500 & 0.12 \\
\hline
\end{tabular}




\section{Elevation Map Accuracy}

The mean error (ME), root-mean square error (RMSE), and standard deviation of error (SDE) were used to estimate the combined horizontal and vertical uncertainties in the final DEMs (Brasington and others, 2000; Brasington and others, 2003; Lane and others, 2003; Fisher and Tate, 2006; Wheaton and others, 2010; Milan and others, 2011). The ME, RMSE, and SDE were calculated based on differences (expressed in meters) between the RTK-GNSS survey check point elevations and the DEM elevations at those same locations using the formulas reported in Fisher and Tate (2006) (R Core Team, 2020). Although RMSE is a widely used measure of error in mapping applications, more recent studies (since 2006) favor the use of SDE because it is a more complete statistical description of error (for example, Fisher and Tate, 2006). The SDE was calculated from the ME, which can be positive or negative depending on systematic errors in elevation (Fisher and Tate, 2006).

The ME, RMSE, and SDE values were calculated separately for the wetted channel and non-wetted channel areas and then averaged. Errors associated with the final DEMs are presented in table 5. The mean ME, RMSE, and SDE values for all 10 study areas were 0.04 meter $(0.13$ foot $), 0.11$ meter ( 0.36 foot), and 0.10 meter $(0.33$ foot $)$, respectively. The errors associated with the final DEMs were derived from at least 758 RTK-GNSS survey points collected within the wetted channel (table 4) and at least 198 RTK-GNSS survey check points collected on the floodplain (or the non-wetted channel) (table 5). For comparison, the mean RMSE and SDE values for all 10 study areas based on 2015 DEMs were 0.14 meter ( 0.45 foot), and 0.14 meter (0.45 foot), respectively (Hempel, 2020).

\section{Elevation-Change Maps and Uncertainty Estimates}

A probabilistic thresholding method, developed specifically for elevation-change detection, was used to generate elevationchange maps and to distinguish real elevation changes caused by geomorphic processes from noise caused by interpolation errors within the DEM (Li, 1988; Fisher, 1998; Brasington and others, 2000; Brasington and others, 2003; Lane and others, 2003; Fisher and Tate, 2006; Wechsler and Kroll, 2006; Wheaton and others, 2010; Milan and others, 2011; Hempel, 2020). First, DEMs from 2020 were re-sampled (or coarsened) from a pixel size of 0.75 meter to a pixel size of 2 meters to match the resolution of DEMs from 2015 using the resample function from the raster package in R (Hempel, 2020; R Core Team, 2020). The SDE values associated with the re-sampled 2020 DEMs were then estimated using the same method described in the "Elevation Map Accuracy" section and are listed in table 6. The DEMs from 2015 and 2020 were cropped to the area over which elevation data from both years were present using the mask function from the raster package in $\mathrm{R}$ ( $\mathrm{R}$ Core Team, 2020).

Elevation-change detection thresholds associated with 95-percent confidence limits were calculated by propagating errors, specifically the SDE values reported in table 6, associated with DEMs from 2015 and re-sampled DEMs from 2020 using equation 3 reported in Wheaton and others (2010). The maximum elevation-change detection threshold associated with a 95-percent confidence interval was 0.47 meter (1.54 feet) or less for all 10 study areas (table 6). See Hempel (2020) for an expanded discussion on the influence of different confidence limits on elevation-change maps.

Elevation-change rasters for each study area were generated by subtracting the 2015 DEMs from the re-sampled 2020 DEMs and then thresholding the resulting elevation-change rasters by

Table 5. Summary of the combined horizontal and vertical uncertainties in digital elevation models (DEMs) from Fountain Creek, southeastern Colorado, 2020.

\begin{tabular}{ccccc}
\hline Study area & $\begin{array}{c}\text { Mean error, in } \\
\text { meters }^{1}\end{array}$ & $\begin{array}{c}\text { Root mean square error, } \\
\text { in meters }\end{array}$ & $\begin{array}{c}\text { Standard deviation of } \\
\text { error, in meters }^{1}\end{array}$ & $\begin{array}{c}\text { Number of check points collected on the } \\
\text { floodplain to assess the accuracy of the DEM }\end{array}$ \\
\hline 01 & 0.06 & 0.15 & 0.13 & 358 \\
02 & 0.03 & 0.11 & 0.11 & 294 \\
03 & 0.04 & 0.09 & 0.08 & 198 \\
04 & 0.05 & 0.10 & 0.08 & 211 \\
05 & 0.04 & 0.10 & 0.09 & 414 \\
06 & 0.03 & 0.08 & 0.08 & 1,388 \\
07 & 0.02 & 0.11 & 0.10 & 293 \\
08 & 0.06 & 0.12 & 0.11 & 706 \\
09 & 0.03 & 0.13 & 0.13 & 266 \\
10 & 0.03 & 0.13 & 0.12 & 423 \\
Mean & 0.04 & 0.11 & 0.10 & 455 \\
\hline
\end{tabular}

${ }^{1}$ Calculated using formulas reported in Fisher and Tate (2006). 
the 95-percent confidence limits reported in table 6 (R Core Team, 2020). The elevation-change rasters were overlaid on hillshade rasters generated from the re-sampled $2020 \mathrm{DEMs}$ using the hillShade function from the raster package in $\mathrm{R}(\mathrm{R}$ Core Team, 2020). Consequently, areas colored in gray hillshade represented areas with no detectable elevation change (or changes smaller than the 95-percent confidence limit) from 2015 to 2020. Color scale-bars were adjusted to linearly span the maximum and minimum elevation-change values within each study area. Lastly, areas encompassing human-made infrastructure characterized by complex topography that may have contributed to added uncertainty in elevation-change estimates at study areas 2 and 10 were added to the elevation-change maps. The final elevation-change maps are presented in sheets $1-10$.

\section{Elevation-Change Maps and Geomorphic Changes between 2015 and 2020}

Study areas along Fountain Creek underwent a range of geomorphic responses between 2015 and 2020 that often depended on the dominant channel pattern and were largely similar to the changes that occurred between 2015 and 2019 reported by Hempel (2020). Lateral migration occurred in all 10 study areas where meandering or braided was the dominant channel planform pattern (study areas 01, 04, 05, 06, 07, and 08; tables 1 and 7). Sediment deposition within a side channel occurred less often and exclusively within study areas characterized as meandering or braided (study areas 01 and 06; tables 1 and 7). Overall, elevation changes in meandering

Table 6. Standard deviation of error associated with re-sampled 2020 digital elevation models (DEMs), elevation-change detection thresholds associated with the 95-percent confidence limit, and percentage of the study area that underwent detectable change for Fountain Creek elevation-change maps, 2015-20.

\begin{tabular}{cccc}
\hline Study area & $\begin{array}{c}\text { Standard deviation of error } \\
\text { associated with resampled 2020 } \\
\text { DEMs, in meters }\end{array}$ & $\begin{array}{c}\text { Elevation-change detection threshold associated } \\
\text { with the 95-percent confidence limit, in meters }{ }^{1}\end{array}$ & $\begin{array}{c}\text { Percentage of study area that } \\
\text { underwent detectable change }\end{array}$ \\
\hline 01 & 0.18 & 0.45 & 28 \\
02 & 0.15 & 0.43 & 7 \\
03 & 0.13 & 0.37 & 23 \\
04 & 0.11 & 0.35 & 30 \\
05 & 0.15 & 0.40 & 24 \\
06 & 0.12 & 0.34 & 29 \\
07 & 0.13 & 0.37 & 27 \\
08 & 0.16 & 0.42 & 11 \\
10 & 0.16 & 0.41 & 4 \\
\hline
\end{tabular}

${ }^{1}$ Calculated using equation 3 reported by Wheaton and others, 2010.

Table 7. Summary of geomorphic responses at all 10 study areas on Fountain Creek, southeastern Colorado, based on elevationchange maps, 2015-20.

\begin{tabular}{ccc}
\hline Study area & Survey years & Summary of geomorphic response based on elevation-change maps \\
\hline 01 & $2015-20$ & Lateral migration; erosion within the active channel; deposition within side channel \\
02 & $2015-20$ & Bank erosion \\
03 & $2015-20$ & Bank erosion; deposition within the active channel \\
04 & $2015-20$ & Lateral migration; deposition on the floodplain \\
05 & $2015-20$ & Lateral migration; deposition on the floodplain \\
06 & $2015-20$ & Lateral migration; deposition within side channel \\
07 & $2015-20$ & Lateral migration; deposition on the floodplain \\
08 & $2015-20$ & Lateral migration; bank erosion; deposition within the active channel \\
09 & $2015-20$ & Deposition within the active channel \\
10 & $2015-20$ & Minor deposition on the floodplain \\
\hline
\end{tabular}


or braided study areas were also wider spread, occurring over roughly double the percentage of the study area that underwent change compared to other study areas (tables 1 and 6).

In comparison to study areas where meandering or braided was the dominant channel planform pattern, localized bank erosion occurred predominantly in study areas characterized as straight (study areas 02 and 03; tables 1 and 7). Several geomorphic responses, including erosion or deposition within the active (perennially wetted) channel and deposition on the floodplain, occurred in both straight and meandering study areas (study areas 01,03,04, 50, 07, 08, 09, and 10; tables 1 and 7). Most elevation changes occurred within the active channel, although all study areas were characterized by areas of elevation change that were disconnected from the main channel. Those changes may have been caused by localized sediment reworking during overland flow, the growth or death of vegetation, movement of soil or rip-rap on steep slopes, or anthropogenic earth movement. Lastly, there was no apparent longitudinal pattern in geomorphic responses throughout the study areas. Although it was beyond the scope of this report to determine potential causes of geomorphic change on Fountain Creek, this dataset provides important information for longterm monitoring efforts.

\section{Summary}

The U.S. Geological Survey, in cooperation with Colorado Springs Utilities, has collected topographic data annually since 2012 at 10 study areas along Fountain Creek, Colorado, to document baseline channel conditions and to track geomorphic changes following the implementation of the Southern Delivery System in 2016. The 10 study areas are located between Colorado Springs and the terminus of Fountain Creek at the Arkansas River in Pueblo. The purpose of this report is to present elevation maps based on topographic surveys collected in 2020 and to present maps of elevation change that occurred between 2015, the year just prior to the implementation of the Southern Delivery System, and 2020 at all 10 study areas.

The results of this ongoing monitoring effort can be used to assess long-term changes in land-surface elevation and to advance understanding of the geomorphic response to possible alterations in flow conditions on Fountain Creek. More broadly, these data can be used to determine whether the current rate of change in channel morphology is similar, slower, or more rapid than past changes, determine the extent to which changes in channel morphology can be simulated based on existing channel characteristics or flow patterns, and identify riparian areas with infrastructure that may be susceptible to damage caused by changes in the position or size of the channel.

Elevation and elevation-change maps were developed in Global Mapper, R, and ArcGIS from topographic surveys collected at each study area during the winters of 2015 (from real-time kinematic Global Navigation Satellite Systems) and
2020 (from real-time kinematic Global Navigation Satellite Systems and light detection and ranging). A probabilistic thresholding method was used to identify elevation-change detection thresholds associated with 95-percent confidence limits. Study areas along Fountain Creek underwent a range of geomorphic responses between 2015 and 2020 that were similar to the responses between 2015 and 2019 and were often related to the dominant channel pattern of the study area. Although it was beyond the scope of this report to determine potential causes of geomorphic change on Fountain Creek, this dataset provides important information for long-term monitoring efforts.

\section{References Cited}

Brasington, J., Langham, J., and Rumsby, B., 2003, Methodological sensitivity of morphometric estimates of coarse fluvial sediment transport: Geomorphology, v. 53, no. 3-4, p. 299-316. [Also available at https://doi.org/10.1016/ S0169-555X(02)00320-3.]

Brasington, J., Rumsby, B.T., and McVey, R.A., 2000, Monitoring and modelling morphological change in a braided gravel-bed river using high resolution GPS-based survey: Earth Surface Processes and Landforms, v. 25, no. 9, p. 973-990. [Also available at https://doi.org/10.1002/ 1096-9837(200008)25:9<973:AID-ESP111>3.0.CO;2-Y.]

Esri, 2020, ArcGIS - A complete integrated system: Redlands, Calif., Esri, accessed on June, 30, 2020, at https:/www.esri.com/en-us/arcgis/about-arcgis/overview.

Fenneman, N.M., 1917, Physiographic subdivision of the United States: Proceedings of the National Academy of Sciences of the United States of America, v. 3, no. 1, p. 17-22. [Also available at https://doi.org/10.1073/pnas.3.1.17.]

Fenneman, N.M., and Johnson, D.W., 1946, Physiographic divisions of the conterminous U.S.: USGS Special Map, accessed December 20, 2020, at https://water.usgs.gov/GIS/ metadata/usgswrd/XML/physio.xml.

Fisher, P.F., 1998, Improved modelling of elevation error with geostatistics: GeoInformatica, v. 2, no. 3, p. 215-233. [Also available at https://doi.org/10.1023/A:1009717704255.]

Fisher, P.F., and Tate, N.J., 2006, Causes and consequences of error in digital elevation models: Progress in Physical Geography, v. 30, no. 4, p. 467-489. [Also available at https://doi.org/10.1191/0309133306pp492ra.]

Global Mapper, 2020, Global Mapper-Spatial data processing, analysis, and visualization: Hallowell, Maine, Global Mapper, accessed on June 30, 2020, at https:/www.bluemarblegeo.com/products/global-mapperdownload.php. 
Hansen, W.R., Crosby, E.J., and Shroba, R.R., 1982, Environmental geology of the Front Range urban corridor and vicinity, Colorado, with a section on physical properties and performance characteristics of surficial deposits and rock units in the greater Denver area: U.S. Geological Survey Professional Paper 1230, 99 p. [Also available at https://doi.org/10.3133/pp1230.]

Hempel, L.A., 2020, Elevation and elevation-change maps of Fountain Creek, southeastern Colorado, 2015-19: U.S. Geological Survey Scientific Investigations Map 3456, 10 sheets, 9 p., accessed on June 30, 2020, at https://doi.org/10.3133/sim3456.

Hempel, L.A., Clawges, R.M., and Bauer, M., 2020a, Topographic and sediment size data from Fountain Creek between Colorado Springs and the confluence with the Arkansas River, Colorado, 2019: U.S. Geological Survey data release, https://doi.org/10.5066/P9R00MWF.

Hempel, L.A., Creighton, A.L., and Kisfalusi, Z.D., 2020b, Elevation data from Fountain Creek between Colorado Springs and the confluence of Fountain Creek at the Arkansas River, Colorado, 2020 (ver 2.0, May 2021): U.S. Geological Survey data release, https://doi.org/ 10.5066/P98J7DRO.

Heritage, G.L., Milan, D.J., Large, A.R.G., and Fuller, I.C., 2009, Influence of survey strategy and interpolation model upon DEM quality: Geomorphology, v. 112, no. 3-4, p. 334-344. [Also available at https://doi.org/10.1016/j.geomorph.2009.06.024.]

Hooshyar, M., Kim, S., Wang, D., and Medeiros, S.C., 2015, Wet channel network extraction by integrating LiDAR intensity and elevation data: Water Resources Research, v. 51, no. 12, p. 10029-10046. [Also available at https://doi.org/10.1002/2015WR018021.]

Kohn, M.S., 2017, Topographic survey data of Fountain Creek between Colorado Springs and the confluence of Fountain Creek at the Arkansas River, Colorado, 2012 to 2017: U.S. Geological Survey data release, accessed November 12, 2020, at https://doi.org/10.5066/F7QN65NJ.

Lane, S.T., Westaway, R.M., and Murray Hicks, D., 2003, Estimation of erosion and deposition volumes in a large, gravelbed, braided river using synoptic remote sensing: Earth Surface Processes and Landforms, v. 28, no. 3, p. 249-271. [Also available at https://doi.org/10.1002/esp.483.]

Larsen, L.S., 1981, Soil survey of El Paso County area, Colorado: Washington, D.C., U.S. Department of Agriculture, Soil Conservation Service, $212 \mathrm{p}$.

Li, Z., 1988, On the measure of digital terrain model accuracy: The Photogrammetric Record, v. 12, no. 72, p. 873-877. [Also available at https://doi.org/10.1111/j.1477-9730.1988. tb00636.x.]
Mau, D.P., Stogner, R.W., Sr., and Edelmann, P., 2007, Characterization of stormflows and wastewater treatment-plan effluent discharges on water quality, suspended sediment, and stream morphology for Fountain and Monument Creek watersheds, Colorado, 1981-2006: U.S. Geological Survey Scientific Investigations Report 2007-5104, 76 p., accessed September 10, 2020, at https://doi.org/10.3133/sir20075104.

Milan, D.J., Heritage, G.L., Large, A.R.G., and Fuller, I.C., 2011, Filtering spatial error from DEMs - Implications for morphological change estimation: Geomorphology, v. 125, no. 1, p. 160-171. [Also available at https://doi.org/10.1016/ j.geomorph.2010.09.012.]

$\mathrm{R}$ Core Team, 2020, $\mathrm{R}$ - A language and environment for statistical computing: R Foundation for Statistical Computing, Vienna, Austria. [Also available at https://www.R-project.org/.]

Rydlund, P.H., Jr., and Densmore, B.K., 2012, Methods of practice and guidelines for using survey-grade global navigation satellite systems (GNSS) to establish vertical datum in the United States Geological Survey: U.S. Geological Survey Techniques and Methods, book 11, chap. D1, 102 p. with appendixes, https://doi.org/10.3133/tm11D1.

Sanderson, J.S., Rowan, N., Wilding, T., Bledsoe, B.P., Miller, W.J., and Poff, N.L., 2012, Getting to scale with environmental flow assessment-The watershed flow evaluation tool: River Research and Applications, v. 28, no. 9, p. 1369-1377. [Also available at https://doi.org/10.1002/rra.1542.]

Schumm, S.A., 1985, Patterns of alluvial rivers: Annual Review of Earth and Planetary Sciences, v. 13, no. 1, p. 5-27. [Also available at https://doi.org/10.1146/annurev .ea.13.050185.000253.]

Pipeline, S.D.S., 2014, SDS Pipeline ArcGIS, accessed January 3, 2019, at https://www.arcgis.com/home/item.html?id= 1dd1e00325054be5860da0500e25ff4d.

SDS Water Treatment, 2019, Southern Delivery System (SDS) Water Treatment: Colorado Springs Utilities, accessed December 10, 2020, at https://www.csu.org/ CSUDocuments/sdsgeneralfaq.pdf.

Stogner, R.W., Sr., 2000, Trends in precipitation and streamflow and changes in stream morphology in the Fountain Creek watershed, Colorado, 1939-99: U.S. Geological Survey Water-Resources Investigations Report 00-4130, 48 p. [Also available at https://doi.org/10.3133/wri004130.]

Trimble, D.E., 1980, The geologic story of the Great Plains: U.S. Geological Survey Bulletin 1493, 55 p. [Also available at https://doi.org/10.3133/b1493.] 
von Guerard, P., 1989, Suspended sediment and sedimentsource areas in the Fountain Creek drainage basin upstream from Widefield, southeastern Colorado: U.S. Geological Survey Water Resources Investigations Report 88-4136, 36 p. [Also available at https://doi.org/10.3133/wri884136.]

Water Technology, 2019, Southern Delivery System (SDS) Water Project, Colorado, accessed September 28, 2019, at https://www.water-technology.net/projects/ southern-delivery-system-water-project/.
Wechsler, S.P., and Kroll, C.N., 2006, Quantifying DEM uncertainty and its effect on topographic parameters: Photogrammetric Engineering and Remote Sensing, v. 72, no. 9, p. 1081-1090. [Also available at https://doi.org/10.14358/ PERS.72.9.1081.]

Wheaton, J.M., Brasington, J., Darby, S.E., and Sear, D.A., 2010, Accounting for uncertainty in DEMs from repeat topographic surveys-Improved sediment budgets: Earth Surface Processes and Landforms, v. 35, p. 136-156. 
Publishing support provided by the Science Publishing Network, Denver Publishing Service Center

For more information concerning the research in this report, contact the Director, USGS Colorado Water Science Center

Box 25046, Mail Stop 415

Denver, CO 80225

(303) 236-6900

Or visit the Colorado Water Science Center website at https://www.usgs.gov/centers/co-water 
